\title{
Influence of benthic macroinvertebrates on the erodability of estuarine cohesive sediments: Density- and biomass-specific responses
}

\author{
Erik Kristensen ${ }^{\mathrm{a}, *}$, João Magalhães Neto ${ }^{\mathrm{b}}$, Morten Lundkvist ${ }^{\mathrm{a}, \mathrm{c}}$, Lars Frederiksen ${ }^{\mathrm{a}}$, \\ Miguel Ângelo Pardal ${ }^{\mathrm{b}}$, Thomas Valdemarsen ${ }^{\mathrm{a}}$, Mogens Rene Flindt ${ }^{\mathrm{a}}$ \\ a Institute of Biology, University of Southern Denmark, Campusvej 55, 5230 Odense M, Denmark \\ ${ }^{\mathrm{b}}$ IMAR - Institute of Marine Research (C.I.C.), c/o Department of Zoology, Faculty of Sciences and Technology, University of Coimbra, \\ Largo Marquês de Pombal, 3004-517 Coimbra, Portugal \\ ${ }^{c}$ DHI - Water, Environment, Health, Agern Allé 5, 2970 Hørsholm, Denmark
}

\section{A R T I C L E I N F O}

\section{Article history:}

Received 9 April 2013

Accepted 26 September 2013

Available online 7 October 2013

Regional index term:

Portugal

Mondego Estuary

Keywords:

erosion threshold

erosion rate

behaviour

macrofauna feeding

microphytobenthos

biostabilization

\begin{abstract}
A B S T R A C T
The impact of three dominating benthic invertebrates on sediment stability and erosion conditions of cohesive sediments in the Mondego Estuary, Portugal, was examined in laboratory annular flume experiments. The purpose was to test how the life habits and body size of the three involved species (Hydrobia ulvae, Nereis diversicolor and Scrobicularia plana) in terms of density or biomass influence sediment erosion. All three species decreased the free-stream erosion threshold $\left(u_{\mathrm{c}}\right)$ and increased erosion rate $(E)$, since their feeding activities diminished the surface stabilizing effect of extracellular polymeric substances (EPS) produced by microphytobenthos. S. plana had the highest and $H$. ulvae the lowest impact when related to density (factor of 29 for $u_{\mathrm{c}}$ and factor of 19 for $E$ ), while $H$. ulvae was more important than S. plana when related to biomass (factor of 4 for $u_{\mathrm{c}}$ and factor of 6 for $E$ ). N. diversicolor had intermediate density-specific (4-6 times higher than $H$. ulvae) and lowest biomass-specific (2-3 times lower than $S$. plana) effects on erosion. It appears that faunal erosion impacts preferably should be reported in biomass units for comparative purposes because individual behavioural effects of a smallbodied species like $H$. ulvae functionally can be relatively more important than those of a 100 times heavier S. plana individual. This is clearly evidenced from the strongly diminished response in suspended Chlorophyll- $a$ content in the presence of the former than the latter species, which is caused by an efficient microphytobenthos grazing by $\mathrm{H}$. ulvae. It is also important to emphasize that the total faunal impact on erosion threshold in a certain area is dictated by combination of contributions from individual species. The total outcome is unpredictable and controlled by synergistic and antagonistic speciesspecific effects, species interactions as well as environmental and sediment conditions.
\end{abstract}

(c) 2013 Elsevier Ltd. All rights reserved.

\section{Introduction}

A key characteristic of intertidal mudflats is sediment stability and erosion dynamics. The driving physical, chemical and biological forces and parameters controlling sediment stability often act in opposite directions, increasing or decreasing stability in an unpredictable pattern (e.g. Tolhurst et al., 2006; Lundkvist et al., 2007b). While coarse non-cohesive sediments show predictable relationships between grain size and erosion threshold (Dyer,

\footnotetext{
* Corresponding author.

E-mail address: ebk@biology.sdu.dk (E. Kristensen).
}

1986; Thompson et al., 2011), the erosion dynamics of cohesive sediments is more complex and difficult to predict alone from physical properties, such as particle size, water content, bulk density, organic content, depositional history and air exposure. The erosion threshold of cohesive coastal sediments is instead under control of biological factors including microphytobenthos activity, macrophyte growth as well as meio- and macrofauna activity (Widdows et al., 1998; Paterson et al., 2000; De Brouwer et al., 2005). Biostabilization is particularly dependent on the formation of a surface film of extracellular polymeric substances (EPS) generated primarily by microphytobenthos (Quaresma et al., 2004; Spears et al., 2008). Thus, EPS films are known increase the critical shear stress 3 fold under replete light conditions (Lundkvist et al., 2007b). 
Benthic macrofauna markedly affects the stability of cohesive sediments (Ciutat et al., 2007; Soares and Sobral, 2009). Their impact is species-specific and strongly depends on feeding mode, life habit and size (Orvain et al., 2012). Macrofauna may counteract biostabilization of surface particles through grazing on benthic microalgae and thus lowering the associated coverage of EPS (Friend et al., 2003). Furthermore, small benthic faunal (e.g. the gastropod Hydrobia ulvae) may disturb the sediment surface by creating tracks and forming faecal aggregates that, together with the animal itself, increases the overall bed roughness, making the surface more susceptible to hydrodynamic erosive forces (Blanchard et al., 1997; Andersen et al., 2002). Also sediment reworking by larger burrowing and deposit-feeding macrofauna (e.g. the polychaete Nereis diversicolor and the bivalve Scrobicularia plana) may change shear strength by altering sediment properties and destabilizing sediments beyond the surface layer (Botto and Iribarne, 2000; Andersen and Pejrup, 2002; Andersen et al., 2002; Widdows et al., 2009). Benthic animals may to a lesser extent also stabilize the sediment e.g. through their mucus secretions while moving on the sediment surface and by reinforcing burrow structures (Palomo and Iribarne, 2000; Le Hir et al., 2007).

It is therefore evident that multiple and species-specific processes invoked by benthic macrofauna on sediment erosion are involved at different spatial scales, which prevent generalizations and comparisons among species and locations. Key features in this respect are the size and behaviour of the fauna. It is obvious that a subsurface-feeder with a large body size (e.g. the gram sized lugworm, Arenicola marina) potentially will have larger individualspecific impact than small epifauna (e.g. the milligram sized mudsnail, Hydrobia ulvae) (Orvain et al., 2006; Valdemarsen et al., 2011). Despite the fact that the small species are commonly found in orders of magnitude higher density and often higher total biomass than larger species, their impact on sediment stability tends to be neglected due to their relatively modest individualspecific contribution.

This study aims at comparing the impact of three common macroinvertebrate species with different life habits and size (Hydrobia ulvae, Nereis diversicolor and Scrobicularia plana) on the erodability of cohesive estuarine sediments. The three species were examined individually at various abundances using laboratory annular flumes to determine sediment erosion characteristics. We hypothesize that any comparison of effects on sediment stability among fauna species must consider not only the density, but also 1) the biomass of the fauna, and 2) the life habit and feeding mode of the involved species.

\section{Materials and methods}

\subsection{Study site and sampling}

Sampling was conducted in the mesohaline southern arm of the Mondego Estuary, Portugal $\left(40^{\circ} 07^{\prime} 46^{\prime \prime} \mathrm{N}\right.$; $\left.08^{\circ} 50^{\prime} 48^{\prime \prime} \mathrm{W}\right)$ (Cardoso et al., 2005). A high intertidal sampling site with cohesive muddy sediment ( $85 \%$ of particles in the $63-38 \mu \mathrm{m}$ size class and organic matter content of $5-8 \%$ ) was selected (Azeiteiro and Marques, 1999). The sediment surface was coated with a well-developed microphytobenthic film consisting of diatoms and cyanobacteria. The benthic fauna was dominated by the gastropod Hydrobia ulvae, the polychaete Nereis (Hediste) diversicolor and the bivalve Scrobicularia plana (Lillebø et al., 1999). H.ulvae is a small $(<0.6 \mathrm{~cm})$ epipsammic diatom browser (Fenchel et al., 1975) that occurs in high densities ( $>100,000 \mathrm{~m}^{-2}$, Lillebø et al., 1999). The medium sized $(<10 \mathrm{~cm}) N$. diversicolor is less abundant (up to $2000 \mathrm{~m}^{-2}$, Cardoso et al., 2004). It lives in U-shaped ventilated burrows to less than $20 \mathrm{~cm}$ depth (Kristensen, 1984) and is a non-selective surface deposit-feeder or suspension-feeder (Riisgård, 1991). S. plana is a medium sized $(<4 \mathrm{~cm})$ infaunal species that occur in relatively low densities (up to $1000 \mathrm{~m}^{-2}$, Verdelhos et al., 2005). It feeds nonselectively on surface deposits by the use of its inhalant siphon (Zwarts et al., 1994).

Sediment for experiments was collected by hand from the top $3 \mathrm{~cm}$, brought to the laboratory and sieved through a 1-mm mesh to remove shells and other larger fragments. Specimens of macrofauna, Hydrobia ulvae, Nereis diversicolor and Scrobicularia plana, were sampled in the same area as the sediment and kept under experimental conditions $\left(10-15{ }^{\circ} \mathrm{C}\right)$ until use. Seawater was collected in the nearby Buarcos Bay $\left(40^{\circ} 09^{\prime} 49^{\prime \prime} \mathrm{N}\right.$; $\left.08^{\circ} 52^{\prime} 48^{\prime \prime} \mathrm{W}\right)$, filtered through Whatman GF/C filters and mixed with distilled water to a final estuarine salinity of 20-22.

\subsection{Annular flume design}

Sediment stability was determined in annular laboratory miniflumes. The flumes consisted of two acrylic plastic tubes with different diameter $(40.6$ and $50 \mathrm{~cm})$ that were fixed onto an acrylic base creating a $4.2 \mathrm{~cm}$ wide annulus. The basal area of the channel was $0.06 \mathrm{~m}^{2}$ and given the height of $36 \mathrm{~cm}$ it contained a maximum water volume of $21.6 \mathrm{~L}$. The water current in the channel was controlled by an AC-servo motor with an integrated engine driver (MAC motor) supplied by a $48 \mathrm{~V}$ power supply. The MAC motor was interfaced to a data logging PC. All data were stored by acquisition software that also regulated the MAC motor output from voltage to engine rounds per minute (RPM). The MAC motor was attached to the lid of the flume and connected to six equidistantly placed paddles that induced the current in the channel. The MAC motor RPM was calibrated against free-stream current velocity $\left(u, \mathrm{~m} \mathrm{~s}^{-1}\right)$ by visually tracking neutrally buoyant particles in the water column. Velocity measurements carried out at various RPM provided the following empirical relationship: $u=R P M \times 0.0011$.

Two sampling ports located $15 \mathrm{~cm}$ above the base on opposite sides of the outer channel wall of the flume were used for water sampling and turbidity measurements. The turbidity port was equipped with a SeaPoint ${ }^{\circledR}$ Turbidity Meter (STM) that detected backscattered light from suspended sediment particles at $880 \mathrm{~nm}$. The STM was interfaced to the data logging PC with continuous logging at a frequency of $1 \mathrm{~Hz}$.

\subsection{Experimental}

After sieving, the sediment was transferred to a plastic container, covered with water and purged with $\mathrm{N}_{2}$ for $24 \mathrm{~h}$ to kill all remaining fauna by asphyxiation. Subsequently, the sediment bed was prepared by transferring a slurry consisting of $3 \mathrm{~L}$ sediment mixed with $0.5 \mathrm{~L}$ of filtered seawater into the flume. This procedure assured a $\sim 6 \mathrm{~cm}$ deep sediment layer with smooth surface in the flume channel. The flume was then filled with $17 \mathrm{~L}$ of filtered seawater, which was introduced carefully assuring minimal disturbance to the sediment bed. The seawater was pre-mixed with $\sim 0.5 \mathrm{~L}$ fresh surface sediment to create an upper $1 \mathrm{~cm}$ layer containing live microphytobenthos. The sediment was allowed to consolidate for $24 \mathrm{~h}$ under experimental conditions $\left(10-15{ }^{\circ} \mathrm{C}\right.$ ) while the flume was maintained under a constant free-stream current velocity $(u)$ well below the critical erosion threshold (about $0.02 \mathrm{~m} \mathrm{~s}^{-1}$ ). The flume water was aerated to avoid oxygen depletion, but gently enough to prevent sediment disturbance. A 12 light/12 dark cycle was maintained by tube lamps (Philips TL-D $36 \mathrm{~W} / 54-765$ ) placed $0.5 \mathrm{~m}$ above the water surface. The light intensity was monitored continuously using a LI-COR Data Logger (LI1000) to assure an intensity of at least $100 \mu \mathrm{mol}$ photons $\mathrm{m}^{-2} \mathrm{~s}^{-1}$ at 
Table 1

Area-specific density and biomass of Hydrobia ulvae, Nereis diversicolor, and Scrobicularia plana selected for flume experiments.

\begin{tabular}{lcc}
\hline Species & Density $\left(\mathrm{m}^{-2}\right)$ & Biomass $\left(\mathrm{g} \mathrm{AFDW} \mathrm{m}^{-2}\right)$ \\
\hline Hydrobia ulvae & 3333 & 4.5 \\
& 5000 & 6.6 \\
& 6667 & 9.0 \\
Nereis diversicolor & 333 & 27.6 \\
& 667 & 52.6 \\
Scrobicularia plana & 1333 & 110.4 \\
& 250 & 38.7 \\
& 433 & 69.2 \\
& 600 & 96.9 \\
\hline
\end{tabular}

the sediment surface, which was considered optimal for the microphytobenthos (Lundkvist et al., 2007a).

Three separate experimental series were carried out; one for each animal species (Exp HU with Hydrobia ulvae, Exp ND with Nereis diversicolor and Exp SP with Scrobicularia plana). Four miniflumes were used in each series; one control $\left(0\right.$ ind $\left.\mathrm{m}^{-2}\right)$ and 3 holding different densities and biomasses (Table 1$)$. Average sized individuals of the fauna species were weighed and introduced to the flumes in the chosen densities about $2 \mathrm{~h}$ after termination of the initial erosion cycle at day 0 (Table 2). The wet weight of animals was converted to ash free dry weight (AFDW) using the following pre-determined conversion factors: $H$. ulvae, $\mathrm{AFDW}=0.205 \times \mathrm{DW} ; \mathrm{N}$. diversicolor, $\mathrm{AFDW}=0.817 \times \mathrm{DW}$; S. plana, $\mathrm{AFDW}=0.148 \times \mathrm{DW}$.

Each experiment was composed of two erosion cycles. The first initial cycle was performed at day 0 to determine the initial stability of sediment devoid of fauna and microphytobenthos. The second main cycle was performed at day 5 to determine the final stability of sediment affected by fauna and microphytobenthos. Each erosion cycle started with 2 min quiescence, $u=0 \mathrm{~m} \mathrm{~s}^{-1}$, to detect background turbidity. Subsequently, the free-stream current velocity was incremented in steps of $0.05 \mathrm{~m} \mathrm{~s}^{-1}$ until logger saturation was achieved (Fig. 1). The current velocity in each step was maintained for $15 \mathrm{~min}$ to assure steady state of suspended sediment before advancing to the next step. Turbidity (STM output) was measured continuously during erosion cycles. Aeration was stopped during erosion cycles and restarted $1 \mathrm{~h}$ after the end of each cycle or when STM output (water turbidity) had decreased to $2 / 3$ of its maximum. Erosion cycles were always executed during the light period.

Water samples were collected at every velocity step (after $10 \mathrm{~min}$ ) for determination of suspended sediment concentration (SSC, $\mathrm{g} \mathrm{L}^{-1}$ ) and during the final step for Chlorophyll-a (Chl- $a$, $\mu \mathrm{g} \mathrm{L}^{-1}$ ). Sampled water was replaced continuously to avoid changes in water level in the flumes. SSC was determined as the dry material recovered after filtering through pre-weighted Whatman GF/C filters and related to the corresponding STM output to establish a calibration curve. Water samples $(n=3)$ for determination of suspended Chl- $a$ were filtered onto Whatman GF/C filters and extracted in $5 \mathrm{~mL}$ of $96 \%$ ethanol in darkness for $20 \mathrm{~h}$ (Jespersen and

Table 2

Time schedule for key events of each flume experiment.

\begin{tabular}{ll}
\hline Event & Time (days) \\
\hline Sediment bed prepared & -1 \\
Sediment compaction & -1 to 0 \\
First erosion cycle & 0 \\
Fauna introduced & 0 \\
Fauna acclimation & $0-5$ \\
Second erosion cycle & 5 \\
\hline
\end{tabular}
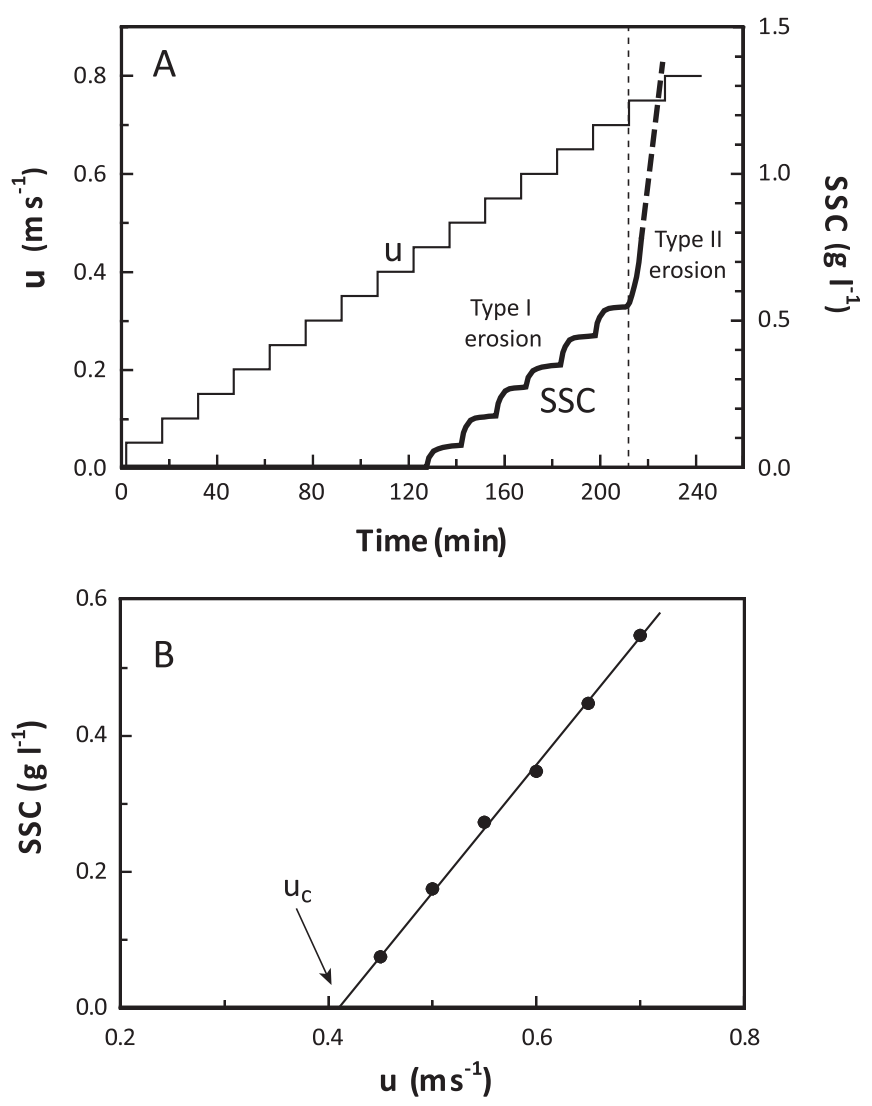

Fig. 1. (A) The outcome of a typical erosion cycle with $0.05 \mathrm{~m} \mathrm{~s}^{-1}$ increments in current velocity. The thin line represents free-stream current velocity $(u)$. The thick line represents the stepwise increase in suspended sediment concentration (SSC) within the Type I erosion zone and the more erratic and unpredictable pattern (dashed part) within the Type II erosion zone. The vertical dashed line separates Type I and Type II erosion. (B) Regression used to estimate the erosion threshold. The critical current velocity $\left(u_{\mathrm{c}}\right)$ was estimated as the zero SSC intercept from a regression of measured SSC against $u$.

Christoffersen, 1987). After centrifugation at 3000 RPM for $10 \mathrm{~min}$, the supernatant was analyzed spectrophotometrically at 665 and $750 \mathrm{~nm}$.

\subsection{Erosion threshold and erosion rates}

The erosion threshold, expressed as critical current velocity $\left(u_{\mathrm{c}}\right.$, $\mathrm{m} \mathrm{s}^{-1}$ ), was estimated as the zero SSC intercept from a regression of measured SSC against $u$ (Fig. 1). SSC values were obtained from calibrated STM readings and corrected for the background level at velocity $0 \mathrm{~m} \mathrm{~s}^{-1}$ measured prior the start of erosion cycles. The linear regression was computed using time averaged steady SSC from each Type I erosion step. The use of and distinction between erosion Type I and II (Fig. 1) follow the description given by Parchure and Mehta (1985), Amos et al. (1992) and Neumeier et al. (2007).

Net erosion rates $\left(E, \mathrm{mg} \mathrm{m} \mathrm{m}^{-2} \mathrm{~s}^{-1}\right)$ were estimated from SSC at the end of the time step with the highest free-stream current velocity within the Type I erosion regime: $E=\mathrm{d} M /$ $\mathrm{d} t=\left(\mathrm{SSC}_{\mathrm{end}}-\mathrm{SSC}_{\mathrm{start}}\right)^{*} V / A^{*} \Delta t$, where $M$ is the eroded mass, $\mathrm{SSC}_{\mathrm{end}}$ is final suspended sediment concentration in the last time step, $\mathrm{SSC}_{\text {start }}$ is the suspended sediment concentration at the end of the previous time step, $V$ is the flume volume in litres, $A$ is the flume channel basal area $\left(0.06 \mathrm{~m}^{2}\right)$ and $\Delta t$ is the duration of the last step in seconds. This method follows the description by Quaresma et al. (2004). The use of the last free-stream current velocity step within 
the Type I erosion region assures that no bias was introduced due to irregular resuspension events typical for Type II erosion.

\subsection{Statistical analysis}

Least squares linear regressions were used to determine the dependence of erosion thresholds $\left(u_{\mathrm{c}}\right)$, erosion rate $(E)$ and Chlorophyll- $a$ on fauna density and biomass. Differences in slopes of regressions in the three erosion experiments (Exp HU, Exp ND and Exp SP) were assessed using ANCOVA based on the $F$ distribution. Correlation matrices were computed after standardization using the parametric correlation coefficient (Pearson's $r$ ) (Legendre and Legendre, 1998). Significance level of 0.05 was considered for all test performances.

\section{Results}

\subsection{Density- and biomass-specific fauna effects on sediment} erodability

The day 5 erosion results showed responses with increasing faunal abundance that were different for the three benthic species, Hydrobia ulvae (Exp HU), Nereis diversicolor (Exp ND) and Scrobicularia plana (Exp SP), and also very much different depending on how the fauna was quantified (i.e. density or biomass) (Fig. 2).

The first erosion cycle at day 0 was without biological influence and gave an average erosion threshold $\left(u_{c}\right)$ of $0.30 \pm 0.03 \mathrm{~m} \mathrm{~s}^{-1}$. The second erosion cycle after light exposure of microphytobenthos for 5 days revealed almost a doubling of $u_{\mathrm{c}}\left(0.55 \pm 0.03 \mathrm{~m} \mathrm{~s}^{-1}\right)$ in the three control treatments devoid of fauna (Table 3 ). All experimental series showed an exponential decrease in $u_{\mathrm{c}}$ with fauna abundance within the examined density and biomass range (Fig. 2A, B). While Exp SP had a density-specific $\ln \left(u_{c}\right)$ slope that was 29 and 7 times $(p<0.05)$ steeper than in Exp HU and ND, respectively, the corresponding biomass-specific slopes of Exp SP were about $28 \%$ $(p \sim 0.05)$ of that in Exp HU and 3 times $(p<0.05)$ higher than in Exp ND (Table 3). Exp ND always showed a modest decrease in $u_{\mathrm{c}}$ with increasing abundance. Although the biomass of Hydrobia ulvae was relatively low (a maximum roughly $10 \%$ of that for other species, Table 1 ) with a $\ln \left(u_{c}\right)$ slope barely significantly different from the other species, it exhibited a much steeper slope than for the density-based relationship.

The free-stream current velocity $(u)$ of the last erosion step within the Type I erosion region was stable at $0.7 \mathrm{~m} \mathrm{~s}^{-1}$ for all three fauna species and abundances. The corresponding suspended sediment concentration (SSC) was about $0.55 \mathrm{~g} \mathrm{~L}^{-1}$ (erosion depth $<3 \mathrm{~mm}$ ) for all fauna control treatments and decreased no
Table 3

Regression parameters obtained from the relationships shown in Figs. 2 and 3 between faunal abundance or biomass (Hydrobia ulvae, Nereis diversicolor and Scrobicularia plana) and free-stream erosion threshold $\left(\ln \left(u_{\mathrm{c}}\right)\right)$, as well as erosion rate ( $E$ rate), and suspended Chlorophyll- $a(\mathrm{Chl}-a)$ at the highest Type I erosion step. Note that the regression for $u_{\mathrm{c}}$ is logarithmic and that the intercept is converted to absolute $u_{\mathrm{c}}$ values.

\begin{tabular}{|c|c|c|c|c|c|c|}
\hline & \multicolumn{2}{|l|}{ Slope } & \multicolumn{2}{|l|}{ Intercept } & \multicolumn{2}{|l|}{$r^{2}$} \\
\hline & Density & Biomass & Density & Biomass & Density & Biomass \\
\hline $\ln \left(u_{\mathrm{c}}\right)$ & $\left(10^{-5}\right)$ & $\left(10^{-3}\right)$ & & & & \\
\hline H. ulvae & -2.0 & -12.7 & 0.53 & 0.53 & 0.811 & 0.823 \\
\hline N. diversicolor & -8.5 & -1.2 & 0.54 & 0.54 & 0.487 & 0.464 \\
\hline S. plana & -57.8 & -3.6 & 0.59 & 0.59 & 0.969 & 0.969 \\
\hline$E$ rate & $\left(10^{-2}\right)$ & $\left(10^{-1}\right)$ & & & & \\
\hline H. ulvae & 1.4 & 102.8 & 134.8 & 134.5 & 0.588 & 0.600 \\
\hline N. diversicolor & 8.0 & 9.4 & 181.6 & 183.1 & 0.612 & 0.586 \\
\hline S. plana & 27.5 & 16.9 & 234.6 & 236.3 & 0.735 & 0.725 \\
\hline Chl- $a$ & $\left(10^{-2}\right)$ & $\left(10^{-1}\right)$ & & & & \\
\hline H. ulvae & -4.1 & -94.3 & 398.8 & 393.6 & 0.139 & 0.514 \\
\hline N. diversicolor & 10.1 & 12.2 & 558.8 & 559.4 & 0.719 & 0.720 \\
\hline S. plana & 76.0 & 47.1 & 311.8 & 314.4 & 0.692 & 0.695 \\
\hline
\end{tabular}

more than $20 \%$ with increasing fauna abundance (Fig. 3A, B). Net erosion rate $(E)$, on the other hand, increased with faunal abundance in all experiments (Fig. 3C, D). Only the density-specific difference between $E$ slopes of Exp HU and SP was significant with the latter having a 20-fold steeper slope (Table 3). This trend was reversed, although not significantly, to a 6-fold steeper slope for Exp HU than SP in the biomass-specific relationships. The increase in $E$ for Exp ND was slow and with no dramatic changes as a function of both density and biomass.

Suspended Chlorophyll- $a$ normalized to SSC showed a densityspecific response in all three experimental series (Fig. 3E). Chl- $a$ per g SSC increased significantly $(p<0.05)$ about 7.5 times faster with increasing density in Exp SP than ND, while an insignificant decreasing trend was observed in Exp HU (Table 3). The biomassspecific relationships showed no significantly different slopes, but the decreasing trend in Exp HU appeared visually stronger, while the suspended Chl- $a$ appeared biomass-wise less affected in Exp SP and Exp ND.

\subsection{Correlation analysis}

Pearson correlation matrices among the examined parameters showed distinct patterns and differences for the three faunal treatments (Table 4$)$. The erosion threshold $\left(\ln \left(u_{c}\right)\right)$ was negatively
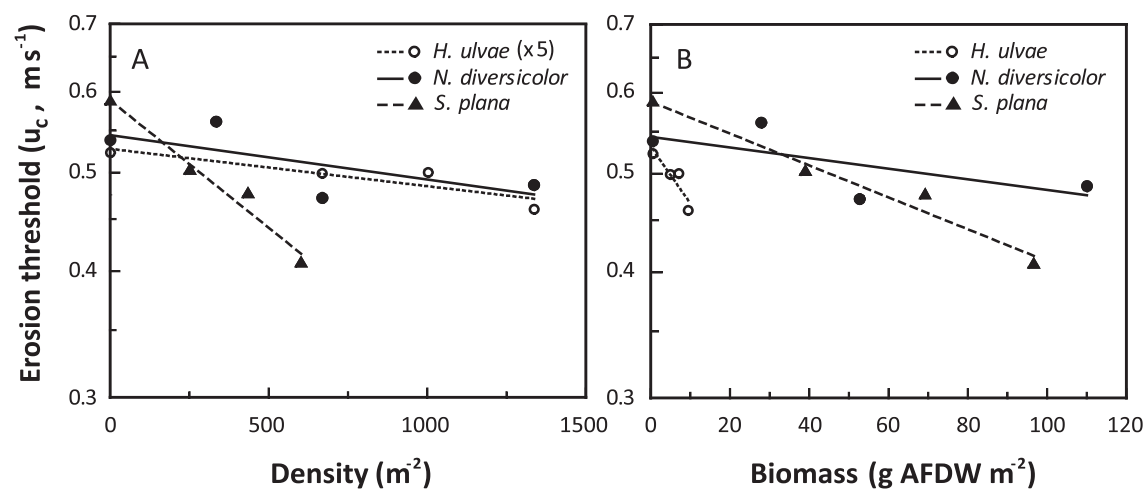

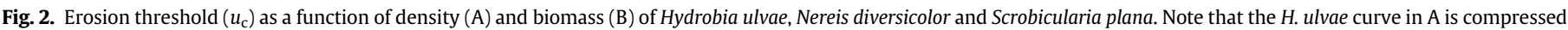
by a factor of 5 . 

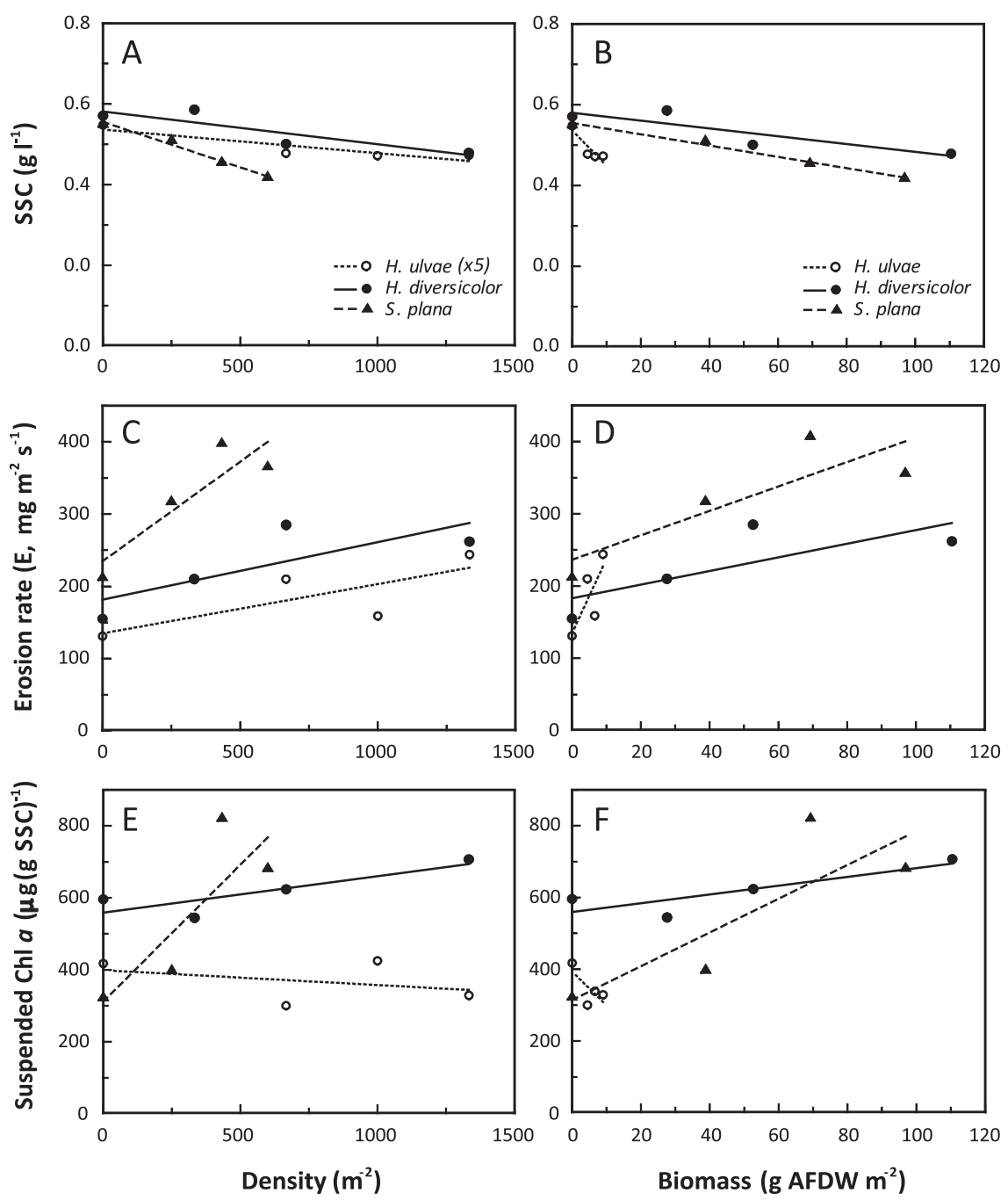

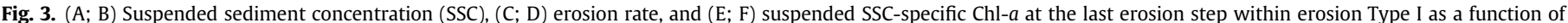
density (left) and biomass (right) of Hydrobia ulvae, Nereis diversicolor and Scrobicularia plana.

correlated to erosion rate ( $E$ rate), but only significantly in Exp HU and SP. Chl- $a$ showed mixed and generally weak correlations with other parameters. The correlation between Chl- $a$ and $\ln \left(u_{c}\right)$ in Exp HU was positive and not significant, while the correlation between Chl- $a$ and $E$ rate in this experiment was negative and significant. The correlations with Chl- $a$ and the other parameters in Exp ND were all weak due to the limited change in Chl- $a$ with abundance of Nereis diversicolor. The correlations between Chl- $a$ and the other

\section{Table 4}

Pearson correlation matrix for the following parameters examined in the experiments: Erosion threshold $\left(\ln \left(u_{\mathrm{c}}\right)\right)$, erosion rate $(E$ rate), and Chlorophyll- $a$ (Chl- $a)$. Results are given in each cell for Hydrobia ulvae (top), Nereis diversicolor (middle), and Scrobicularia Plana (bottom). Significant correlations $(p<0.05)$ are marked with bold.

\begin{tabular}{lrrl}
\hline & $E$ rate & Chl- $a$ & \\
\hline $\ln \left(u_{c}\right)$ & $-\mathbf{0 . 9 6}$ & 0.56 & $\mathrm{Hu}$ \\
& -0.81 & -0.77 & $\mathrm{Nd}$ \\
& $-\mathbf{0 . 9 3}$ & -0.82 & $\mathrm{Sp}$ \\
& & $-\mathbf{0 . 9 6}$ & $\mathrm{Hu}$ \\
& & 0.53 & $\mathrm{Nd}$ \\
& & 0.79 & $\mathrm{Sp}$ \\
\hline
\end{tabular}

parameters in Exp SP were opposite those observed in Exp HU and not significant.

\section{Discussion}

Cohesive sediments free of fauna generally experience high surface stability due to undisturbed growth of microphytobenthos films and the associated high EPS production that binds sediment particles (Austen et al., 1999; Paterson et al., 2000; Whitehouse et al., 2000; Andersen et al., 2002; Lundkvist et al., 2007a). The almost doubled erosion threshold $\left(u_{c}\right)$ during the 5 days between erosion cycles in our defaunated sediment emphasizes that the development of biostabilization through microphytobenthic EPS production is rapid and efficient. However, the three species of benthic fauna examined here all tended to decrease the erosion threshold with increasing density and biomass (Fig. 2). Nevertheless, the overall characteristics and cohesiveness of the applied sediment controls that the free-stream current velocity required to reach Type II erosion remains constant irrespective of fauna species and abundance. The density-specific changes in erosion parameters appear more pronounced for Scrobicularia plana than Hydrobia ulvae and Nereis diversicolor, whereas the biomass-specific 
response was much stronger for $H$. ulvae than the other species. In any case, the erosion threshold did not reach the initial (day 0) level, indicating that some degree of stabilization by EPS always develops in illuminated coastal sediments irrespective of benthic fauna activity.

The differential erosion response to increasing density and biomass of benthic fauna is dependent on their behaviour and life habit. The pronounced negative effect of Hydrobia ulvae on sediment erosion parameters (e.g. 10\% decrease in $u_{c}$ at the highest tested abundance) must be related to these snails feeding by epipsammic browsing of diatoms and other microalgae at the sediment-water interface (Austen et al., 1999). Thus, when a population of $H$. ulvae efficiently grazes microphytobenthos to low abundance, there will subsequently be lower formation of erosion stabilizing EPS (Gerdol and Hughes, 1994; De Deckere et al., 2000; Andersen et al., 2005) and fewer cells (i.e. Chl-a) exposed to resuspension. This is confirmed in our experiment from the $69 \%$ increased erosion rate and $21 \%$ decreased suspended SSC-specific Chl- $a$ at the highest tested $H$. ulvae abundance (Fig. 3). The compensating stabilization of surface sediment resulting from the mucus trails deposited during snail locomotion (Orvain et al., 2003) is apparently not sufficient to counteract for the missing microphytobenthic EPS production. Andersen et al. (2002) observed a doubling of erosion rate with an increase in $H$. ulvae density from 10,000 to 50,000 ind $\mathrm{m}^{-2}\left(\sim 15-75 \mathrm{~g}^{\mathrm{A}}\right.$ AFDW m $\left.\mathrm{m}^{-2}\right)$. A similar doubling in erosion rate estimated by linear extrapolation occurred from 0 to 10,000 ind $\mathrm{m}^{-2}$ in our experiment. In addition to the missing EPS, Andersen et al. (2002) also argued that the massive formation of faecal pellets in the size range of $80-90 \mu \mathrm{m}$ by H. ulvae creates an easily erodible layer of light material on top of the sediment, promoting a lower erosion threshold, while maintaining a high erosion rate (Andersen et al., 2005). Thus, more than $80 \%$ (by weight) of the topmost $5 \mathrm{~mm}$ of an intertidal mudflat may consist of pellets (Andersen, 2001). Although we have no observations of such pellets in our experiment, they may be partly responsible for the excessively high erodability in the presence of $H$. ulvae.

In contrast, Nereis diversicolor had only limited impact on all our measured erosion parameters, exhibiting only $1 \%$ decrease in $u_{c}, 5 \%$ increase in $E$ rate and $2 \%$ increase in suspended SSC-specific Chl- $a$ per $10 \mathrm{~g} \mathrm{AFDW} \mathrm{m}^{-2}$ (Figs. 2 and 3 ). There is some controversy about the effect of this polychaete species on sediment erodability. Some studies consider this species a stabilizer, as judged from its influence on the shear strength properties and an apparent increased erosion threshold of the sediment as a function of abundance (Meadows and Tait, 1989; Meadows et al., 1990; Fernandes et al., 2006). Other studies refer to the destabilizing effect of $N$. diversicolor from its influence on the colonization of benthic diatoms and surface topography by a high level of surface activity while searching for food (Underwood and Paterson, 1993; Widdows et al., 2009). However, the slight destabilizing effect of $N$. diversicolor in our experiment suggests that this species may have counteracting destabilizing and stabilizing behaviours. $N$. diversicolor foraging activities at the sediment surface form tracks, burrow openings and other irregularities ('lebensspuren', Abel, 1935 ) that are easier exposed to drag by water currents and thus increased erodability (Le Hir et al., 2007). In contrast, the massive formation of mucus by $N$. diversicolor, which completely coats the structures formed by its bioturbation, causes a strong cohesion among particles and consequently decreases the sediment erodability (Meadows et al., 1990; Murray et al., 2002). It appears that the direct grazing effect of this species on microphytobenthos is negligible as indicated by the increase in SSC-specific Chl- $a$ content with increasing abundance.

The facultative suspension-feeder, Scrobicularia plana, has a strong impact on sediment stability compared with Nereis diversicolor, but not to a higher extent than for Hydrobia ulvae when given in biomass units. It decreases $u_{\mathrm{c}}$ by $3 \%$, increase $E$ rate by $7 \%$ and increases suspended SSC-specific Chl- $a$ by $11 \%$ per $10 \mathrm{~g} \mathrm{AFDW} \mathrm{m}^{-2}$ (Figs. 2 and 3 ). The more pronounced response when related to population density than biomass variations (Figs. 2 and 3 ) is due to its large body size and distinct feeding habit (Orvain, 2005). The erodability is strongly enhanced when it actively collects food by siphoning surface and subsurface sediments surrounding its semi-permanent burrows (Hughes, 1969). The inhalant siphon disrupts any surface stability created by microphytobenthos and alters bed roughness, and thus the critical shear stress for bed erosion. Moreover, large amounts of pseudofaeces are regularly ejected by the inhalant siphon, while faeces are ejected from the exhalant siphon. Faeces and pseudofaeces then form an easily erodible "fluff" layer on top of the sediment near burrows (Nowell et al., 1981; Widdows et al., 1998). However, the direct grazing effect of this deposit-feeding species on microphytobenthos is surprisingly limited as indicated from the increased SSC-specific Chl- $a$ with increasing abundance.

It is obvious that the individual-specific impact on erosion must be much lower for small-bodied Hydrobia ulvae ( $1.5 \mathrm{mg}$ AFDW) compared with the large-bodied Nereis diversicolor $(\sim 80 \mathrm{mg}$ AFDW) and Scrobicularia plana ( $160 \mathrm{mg}$ AFDW) (Table 3). A comparison of erosion impact by three so different species based on density alone is therefore not advisable. Biomass-dependent comparisons, on the other hand, provide a more reliable measure of species-specific behaviour and life habit impacts on erosion dynamics. Accordingly, it appears that the high number of actively grazing $H$. ulvae individuals per unit biomass actually turns the impact of this species on all observed erosion parameters (e.g. $u_{\mathrm{c}}$ and $E$ rate) several fold stronger than for the other two species. The steep negative biomass-specific effect of this species on suspended Chl- $a$ concentration, on the other hand, confirms the efficient grazing of the numerous small individuals. We therefore propose that the biomass-specific erosion responses are more readily related to behaviour and life habit than the density-specific response, and recommend using the former approach when comparing the abundance effects on sediment erosion among

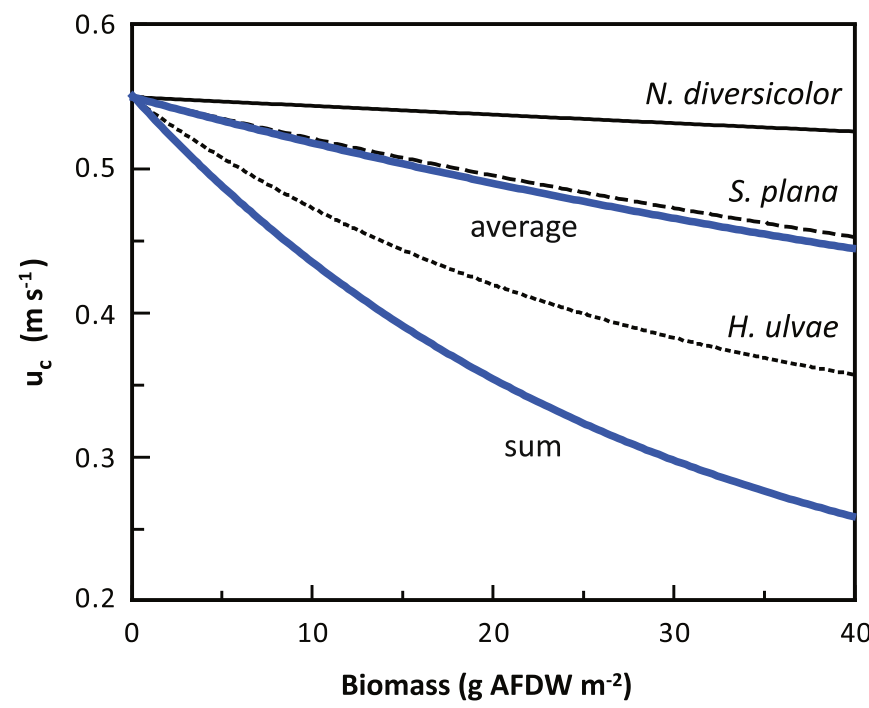

Fig. 4. A conceptual presentation of the likely biomass-dependent change in erosion threshold for Hydrobia ulvae, Nereis diversicolor and Scrobicularia plana. The heavy blue lines represents the average and summed, respectively, combined effects of a fauna mixture with each species set at the same biomass from 0 to $40 \mathrm{~g} \mathrm{AFDW} \mathrm{m}^{-2}$. (For interpretation of the references to colour in this figure legend, the reader is referred to the web version of this article.) 
benthic macrofaunal species. These conclusions merge our two hypotheses, and strengthen our confidence that they both are true.

The exponential relationship between erosion threshold and faunal abundance as depicted in Fig. 2 was chosen partly because of a better correlation, but also based on common sense and knowledge from the literature. A linear relationship cannot be valid for high abundances of e.g. H. ulvae. If our results are extrapolated to biomasses of up to $80 \mathrm{~g} \mathrm{AFDW} \mathrm{m}^{-2}$ as reported in the Mondego Estuary (Lillebø et al., 1999), a linear relationship would predict an erosion threshold close to zero, which is impossible. Furthermore, exponential decrease in erosion threshold with fauna abundance has been observed previously by e.g. Willows et al. (1998) and Orvain (2005). The exponentially decreasing erosion threshold with increasing fauna biomass means that the per individual or biomass unit impact decreases with increasing biomass. Similar non-linear relationships may apply for the other erosion parameters (i.e. erosion rate and suspended $\mathrm{Chl}-a$ ), but we have at present no evidence justifying alternative relationships.

The effects of individual species on the erosion threshold in a benthic community are complex depending on how interspecific interactions affect the activity of the involved species (Orvain et al., 2012). A conceptual presentation of possible combined effects of the three species studied here on erosion threshold is shown in Fig. 4, where the proportion of each species is constant and kept within the biomasses reported for the Mondego and other similar estuaries: Hydrobia ulvae (see above), Nereis diversicolor (40 g AFDW $\mathrm{m}^{-2}$, Scaps, 2002) and Scrobicularia plana (100 g AFDW $\mathrm{m}^{-2}$, Verdelhos et al., 2005). The combined outcome and exact contribution of the individual species to the erosion threshold will be dictated by their disturbance strength. We anticipate two end-member scenarios: 1 . The combined outcome is the average of the involved species effect; and 2. The combined outcome is additive of the involved species effect (Fig. 4). Synergistic and antagonistic effects caused by interactions among species may render both scenarios of this conceptual model invalid (Le Hir et al., 2007; Orvain et al., 2007; Montserrat et al. 2008). The true outcome will most likely be intermediate and unpredictably dictated not only by species-specific effects, but also by their interactions as well as environmental and sediment conditions. There are of course other benthic species with potential impact on erosion conditions present in the Mondego Estuary besides those examined here. These must be surveyed and included before a true total impact of the entire benthic community on erosion conditions can be evaluated for this estuary.

\section{Acknowledgements}

This research was supported by the Danish Council for Independent Research (contract 09-071369) and the Danish Council for Strategic Research (contract 09-063190). J.M. Neto was supported by the Portuguese National Board of Scientific Research (contract SFRH/BPD/20707/2004).

\section{References}

Abel, O., 1935. Vorzeitliche Lebensspuren. Gustav Fischer, Jena.

Amos, C.L., Grant, J., Daborn, G.R., 1992. Sea carousel - a benthic, annular flume. Estuarine, Coastal and Shelf Science 34, 557-577.

Andersen, T.J., 2001. The role of fecal pellets in suspended sediment settling velocities at an intertidal mudflat, the Danish Wadden Sea. In: McAnally, W.H., Mehta, A.J. (Eds.), Coastal and Estuarine Fine Sediment Processes. Elsevier Science, Amsterdam, pp. 387-401.

Andersen, T.J., Jensen, K.T., Lund-Hansen, L., Mouritsen, K.N., Pejrup, M., 2002. Enhanced erodibility of fine-grained marine sediments by Hydrobia ulvae. Journal of Sea Research 48, 51-58.

Andersen, T.J., Lund-Hansen, L.C., Pejrup, M., Jensen, K.T., Mouritsen, K.N., 2005. Biologically induced differences in erodibility and aggregation of subtidal and intertidal sediments: a possible cause for seasonal changes in sediment deposition. Journal of Marine Systems 55, 123-138.

Andersen, T.J., Pejrup, M., 2002. Biological mediation of the settling velocity of bed material eroded from an intertidal mudflat, the Danish Wadden Sea. Estuarine. Coastal and Shelf Science 54, 737-745.

Austen, I., Andersen, T.J., Edelvang, K., 1999. The influence of benthic diatoms and invertebrates on the erodibility of an intertidal mudflat, the Danish Wadden Sea. Estuarine, Coastal and Shelf Science 49, 99-111.

Azeiteiro, U.M.M., Marques, J.C., 1999. Temporal and spatial structure in the suprabenthic community of a shallow estuary (western Portugal: Mondego river estuary). Acta Oecologica 20, 333-342.

Blanchard, G.F., Sauriau, P.-G., Cariou-Le Gall, V., Gouleau, D., Garet, M.-J., Olivier, F. 1997. Kinetics of tidal resuspension of microbiota: testing the effect of sediment cohesiveness and bioturbation using flume experiments. Marine Ecology Progress Series 151, 17-25.

Botto, F., Iribarne, O., 2000. Contrasting effects of two burrowing crabs (Chasmagnathus granulata and Uca uruguayensis) on sediment composition and transport in estuarine environments. Estuarine, Coastal and Shelf Science 51, 141-151.

Cardoso, P.G., Pardal, M.A., Raffaelli, D., Baeta, A., Marques, J.C., 2004. Macroinvertebrate response to different species of macroalgal mats and the role of disturbance history. Journal of Experimental Marine Biology and Ecology 308, 207-220.

Cardoso, P.G., Brandão, A., Pardal, M.A., Raffaelli, D., Marques, J.C., 2005. The resilience of Hydrobia ulvae populations to anthropogenic and natural disturbances. Marine Ecology Progress Series 289, 191-199.

Ciutat, A., Widdows, J., Pope, N.D., 2007. Effects of Cerastoderma edule density on near-bed hydrodynamics and stability of cohesive muddy sediments. Journal of Experimental Marine Biology and Ecology 346, 114-126.

De Brouwer, J.F.C., Wolfstein, K., Ruddy, G.K., Jones, T.E.R., Stal, L.J., 2005. Biogenic stabilization of intertidal sediments: the importance of extracellular polymeric substances produced by benthic diatoms. Microbial Ecology 49, 501-512.

De Deckere, E.M.G.T., van de Koppel, J., Heip, C.H.R., 2000. The influence of Corophium volutator abundance on resuspension. Hydrobiologia 426, 37-42.

Dyer, K.R., 1986. Coastal and Estuarine Sediment Dynamics. Wiley, Chichester, 342 pp.

Fenchel, T., Kofoed, L.H., Lappalainen, A., 1975. Particle size selection of 2 deposit feeders- amphipod Corophium volutator and prosobranch Hydrobia ulvae. Marine Biology 30, 119-128.

Fernandes, S., Sobral, P., Costa, M.H., 2006. Nereis diversicolor effect on the stability of cohesive intertidal sediments. Aquatic Ecology 40, 567-579.

Friend, P.L., Ciavola, P., Cappucci, S., Santos, R., 2003. Biodependent bed parameters as a proxy tool for sediment stability in mixed habitat intertidal areas. Continental Shelf Research 23, 1899-1917.

Gerdol, V., Hughes, R.G., 1994. Effect of Corophium volutator on the abundance of benthic diatoms, bacteria and sediment stability in two estuaries in southeastern England. Marine Ecology Progress Series 114, 109-115.

Hughes, R., 1969. A study of feeding in Scrobicularia plana. Journal of the Marine Biological Association of the United Kingdom 49, 805-823.

Jespersen, A.M., Christoffersen, K., 1987. Measurements of chlorophyll-a from phytoplankton using ethanol as extracting solvent. Archiv fuer Hydrobiologie 109, 445-454.

Kristensen, E., 1984. Life cycle, growth and production in estuarine populations of the polychaetes Nereis virens and $N$. diversicolor. Holarctic Ecology 7, 249-256.

Legendre, L., Legendre, P., 1998. Numerical Ecology, second ed. Elsevier, Amsterdam. 853 pp.

Le Hir, P., Monbet, Y., Orvain, F., 2007. Sediment erodability in sediment transport modelling: can we account for biota effects? Continental Shelf Research 27, 1116-1142.

Lillebø, A.I., Pardal, M.A., Marques, J.C., 1999. Population structure, dynamics and production of Hydrobia ulvae (Pennant) (Mollusca: Prosobranchia) along an eutrophication gradient in the Mondego estuary (Portugal). Acta Oecologica 20, 289-304.

Lundkvist, M., Gangelhof, U., Lunding, J., Flindt, M.R., 2007a. Production and fate of extracellular polymeric substances produced by benthic diatoms and bacteria: a laboratory study. Estuarine, Coastal and Shelf Science 75, 337-346.

Lundkvist, M., Grue, M., Friend, P.L., Flindt, M.R., 2007b. The relative contributions of physical and microbiological factors to cohesive sediment stability. Continental Shelf Research 27, 1143-1152.

Meadows, P.S., Tait, J., 1989. Modification of sediment permeability and shear strength by two burrowing invertebrates. Marine Biology 101, 75-82.

Meadows, P.S., Tait, J., Hussain, S.A., 1990. Effects of estuarine infauna on sediment stability and particle sedimentation. Hydrobiologia 190, 263-266.

Montserrat, F., Van Colen, C., Degraer, S., Ysebaert, T., Herman, P.M.J., 2008. Benthic community-mediated sediment dynamics. Mar. Ecol. Prog. Ser. 372, 43-59.

Murray, J.M.H., Meadows, A., Meadows, P.S., 2002. Biogeomorphological implications of microscale interactions between sediment geotechnics and marine benthos: a review. Geomorphology 47, 15-30.

Neumeier, U., Friend, P.L., Gangelhof, U., Lunding, J., Lundkvist, M., Bergamasco, A., Amos, C.L., Flindt, M., 2007. The influence of fish feed pellets on the stability of seabed sediment: a laboratory flume investigation. Estuarine, Coastal and Shelf Science 75, 347-357.

Nowell, A.R.M., Jumars, P.A., Eckman, J.E., 1981. Effects of biological activity on the entrainment of marine sediments. Marine Geology 42, 133-153.

Orvain, F., 2005. A model of sediment transport under the influence of bioturbation activities: generalisation to a key-species Scrobicularia plana. Marine Ecology Progress Series 286, 43-56. 
Orvain, F., Le Hir, P., Sauriau, P.G., 2003. A model of fluff layer and subsequent bed erosion in the presence of the bioturbator, Hydrobia ulvae. Journal of Marine Research 61, 823-851.

Orvain, F., Sauriau, P.G., Bacher, C., Prineau, M., 2006. The influence of sediment cohesiveness on bioturbation effects due to Hydrobia ulvae on the initial erosion of intertidal sediments: a study combining flume and model approaches. Journal of Sea Research 55, 54-73.

Orvain, F., Le Hir, P., Sauriau, P.-G., Lefebvre, S., 2012. Modelling the effects of macrofauna on sediment transport and bed elevation: application over a crossshore mudflat profile and model validation. Estuarine, Coastal and Shelf Science 108, 64-75.

Orvain, F., Sauriau, P.-G., Le Hir, P., Guillou, G., Cann, P., Paillard, M., 2007. Spatiotemporal variations in intertidal mudflat erodability: Marennes-Oléron Bay,western France. Cont. Shelf Res. 27, 1153-1173.

Palomo, G., Iribarne, O., 2000. Sediment bioturbation by polychaetes feeding may promote sediment stability. Bulletin of Marine Science 67, 249-257.

Parchure, T.M., Mehta, A.J., 1985. Erosion of soft cohesive sediment deposits. Journal of Hydraulic Engineering 111, 1308-1326.

Paterson, D.M., Tolhurst, T.J., Kelly, J.A., Honeywill, C., de Deckere, E.M.G.T., Huet, V. Shayler, S.A., Black, K.S., de Brower, J., Davidson, I., 2000. Variations in sediment properties, Skeffling mudflat, Humber Estuary, UK. Continental Shelf Research 20, 1373-1396.

Quaresma, V., Amos, C., Flindt, M., 2004. The influences of biological activity and consolidation time on laboratory cohesive beds. Journal of Sedimentary Research 74, 184-190.

Riisgård, H.U., 1991. Suspension feeding in the polychaete Nereis diversicolor. Marine Ecology Progress Series 70, 29-37.

Scaps, P., 2002. A review of the biology, ecology and potential use of the common ragworm Hediste diversicolor (O.F. Müller) (Annelida: Polychaeta). Hydrobiologia 470, 203-218.

Soares, C., Sobral, P., 2009. Density-dependent effects of bioturbation by the clam, Scrobicularia plana, on the erodibility of estuarine sediments. Marine and Freshwater Research 60, 737-744.

Spears, B.M., Saunders, J.E., Davidson, I., Paterson, D.M., 2008. Microalgal sedimen biostabilisation along a salinity gradient in the Eden Estuary, Scotland: unravelling a paradox. Marine and Freshwater Research 59, 313-321.
Thompson, C.E.L., Couceiro, F., Fones, G.R., Helsby, R., Amos, C.L., Black, K., Parker, E.R., Greenwood, N., Statham, P.J., Kelly-Gerreyn, B.A., 2011. In situ flume measurements of resuspension in the North Sea. Estuarine, Coastal and Shelf Science 94, 77-88.

Tolhurst, T.J., Friend, P.L., Watts, C., Wakefield, R., Black, K.S., Paterson, D.M., 2006. The effects of rain on the erosion threshold of intertidal cohesive sediments. Aquatic Ecology 40, 533-541.

Underwood, G.J.C., Paterson, D.M., 1993. Seasonal changes in diatom biomass, sediment stability and biogenic stabilization in the Severn Estuary. Journal of the Marine Biological Association of the United Kingdom 73, 871-887.

Valdemarsen, T., Wendelboe, K., Egelund, J.T., Kristensen, E., Flindt, M.R., 2011. Burial of seeds and seedlings by the lugworm Arenicola marina hampers eelgrass (Zostera marina) recovery. Journal of Experimental Marine Biology and Ecology 410, 45-52.

Verdelhos, T., Neto, J.M., Marques, J.C., Pardal, M.A., 2005. The effect of eutrophication abatement on the bivalve Scrobicularia plana. Estuarine, Coastal and Shelf Science 63, 261-268.

Whitehouse, R.J.S., Bassoullet, P., Dyer, K.R., Mitchener, H.J., Roberts, W., 2000. The influence of bedforms on flow and sediment transport over intertidal mudflats. Continental Shelf Research 20, 1099-1124.

Widdows, J., Brinsley, M., Elliot, M., 1998. Use of in situ flume to quantify particle flux (biodeposition rates and sediment erosion) for an intertidal mudflat in relation to changes in current velocity and benthic macrofauna. In: Black, K.S., Paterson, D.M., Cramp, A. (Eds.), Sedimentary Processes in the Intertidal Zone, Geological Society, London, Special Publications, vol. 139, pp. 85-97.

Widdows, J., Brinsley, M.D., Pope, N.D., 2009. Effect of Nereis diversicolor density on the erodability of estuarine sediment. Marine Ecology Progress Series 378, 135143.

Willows, R.I., Widdows, J., Wood, R.G., 1998. Influence of an infaunal bivalve on the erosion of an intertidal cohesive sediment: a flume and modeling study. Limnology and Oceanography 43, 1332-1343.

Zwarts, L., Blomert, A., Spaak, P., deVries, B., 1994. Feeding radius, burying depth and siphon size of Macoma balthica and Scrobicularia plana. Journal of Experimental Marine Biology and Ecology 183, 193-212. 